Article

\title{
Antiallergic Phorbol Ester from the Seeds of Aquilaria malaccensis
}

\author{
Michal Korinek 1,2,+, Vitthal D. Wagh ${ }^{1,+}$, I-Wen Lo ${ }^{1}$, Yu-Ming Hsu ${ }^{1}$, Hsue-Yin Hsu ${ }^{3}$, \\ Tsong-Long Hwang 4,5,6, Yang-Chang Wu ${ }^{1,7,8,9}$, Yuan-Bin Cheng ${ }^{1,10}$, Bing-Hung Chen ${ }^{2,11, *}$ and \\ Fang-Rong Chang ${ }^{1,10,12,13, *}$
}

1 Graduate Institute of Natural Products, College of Pharmacy, Kaohsiung Medical University, Kaohsiung 807, Taiwan; mickorinek@hotmail.com (M.K.); vdwagh22@gmail.com (V.D.W.); iwenlo99@gmail.com (I.-W.L.); u98531010@kmu.edu.tw (Y.-M.H.); yachwu@mail.cmu.edu.tw (Y.-C.W.); jmb@kmu.edu.tw (Y.-B.C.) Department of Biotechnology, College of Life Science, Kaohsiung Medical University, Kaohsiung 807, Taiwan Department of Life Sciences, Tzu Chi University, Hualien 970, Taiwan; hsueyin@mail.tcu.edu.tw

4 Graduate Institute of Natural Products, College of Medicine, Chang Gung University, Taoyuan 333, Taiwan; htl@mail.cgu.edu.tw

5 Research Center for Industry of Human Ecology and Graduate Institute of Health Industry Technology, Chang Gung University of Science and Technology, Taoyuan 333, Taiwan

6 Department of Anesthesiology, Chang Gung Memorial Hospital, Taoyuan 333, Taiwan

7 School of Pharmacy, College of Pharmacy, China Medical University, Taichung 404, Taiwan

8 Chinese Medicine Research and Development Center, China Medical University Hospital, Taichung 404, Taiwan

9 Center for Molecular Medicine, China Medical University Hospital, Taichung 404, Taiwan

10 Center for Infectious Disease and Cancer Research, Kaohsiung Medical University, Kaohsiung 807, Taiwan

11 The Institute of Biomedical Sciences, National Sun Yat-Sen University, Kaohsiung 804, Taiwan

12 Cancer Center, Kaohsiung Medical University Hospital, Kaohsiung 807, Taiwan

13 Department of Marine Biotechnology and Resources, National Sun Yat-sen University, Kaohsiung 804, Taiwan

* Correspondence: bhchen@kmu.edu.tw (B.-H.C.); aaronfrc@kmu.edu.tw (F.-R.C.);

Tel.: +886-7-312-1101 (ext. 2676) (B.-H.C.); +886-7-312-1101 (ext. 2162) (F.-R.C.);

Fax: +886-7-3125-339 (B.-H.C.); +886-7-311-4773 (F.-R.C.)

+ These authors contributed equally to this work.

Academic Editor: Gopinadhan Paliyath

Received: 21 January 2016; Accepted: 10 March 2016; Published: 21 March 2016

Abstract: The Aquilaria malaccensis (Thymelaeaceae) tree is a source of precious fragrant resin, called agarwood, which is widely used in traditional medicines in East Asia against diseases such as asthma. In our continuous search for active natural products, A. malaccensis seeds ethanolic extract demonstrated antiallergic effect with an $\mathrm{IC}_{50}$ value less than $1 \mu \mathrm{g} / \mathrm{mL}$. Therefore, the present research aimed to purify and identify the antiallergic principle of A. malaccensis through a bioactivity-guided fractionation approach. We found that phorbol ester-rich fraction was responsible for the antiallergic activity of $A$. malaccensis seeds. One new active phorbol ester, 12-O-(2Z,4E,6E)-tetradeca-2,4,6-trienoylphorbol-13-acetate, aquimavitalin (1) was isolated. The structure of 1 was assigned by means of $1 \mathrm{D}$ and 2D NMR data and high-resolution mass spectrometry (HR-MS). Aquimavitalin (1) showed strong inhibitory activity in A23187- and antigen-induced degranulation assay with $\mathrm{IC}_{50}$ values of 1.7 and $11 \mathrm{nM}$, respectively, with a therapeutic index up to 71,000 . The antiallergic activities of $A$. malaccensis seeds and aquimavitalin (1) have never been revealed before. The results indicated that $A$. malaccensis seeds and the pure compound have the potential for use in the treatment of allergy.

Keywords: Aquilaria malaccensis seeds; antiallergic; degranulation; phorbol ester; bioactivity-guided fractionation 


\section{Introduction}

Imunoglobulin E (IgE)-mediated allergy is a common immune system disorder affecting approximately 235 million people worldwide, particularly the population in developed countries [1]. Although today we are able to treat the symptoms of allergy, available medications have undesirable effects, especially with a prolonged use. Therefore, there is a need to search for alternative treatment. In general, some natural sources are considered as safe and easily available. Mast cells and their degranulation play a crucial role in IgE-mediated allergic inflammatory responses, such as allergic rhinitis, acute asthma, and atopic eczema [2]. $\beta$-Hexosaminidase is an enzyme released along with histamine from mast cells (rat basophilic leukemia cells, RBL-2H3 cells) upon activation and serves as a well-accepted in vitro model in allergy [3].

Agarwood is a priceless fragrant resinous wood from the Aquilaria species (Thymelaeaceae), which is formed as a defense mechanism to fend off pathogens. Agarwood is widely used in religious, aromatic, and medicinal preparations [4,5]. Aquilaria species has been traditionally used in Thai [6] and Korean [7] medicine, in the Ayurvedic practice, as well as traditional Chinese medicine to treat various diseases, particularly the diseases associated with inflammation [8]. Agarwood from the Aquillaria species has been used as cardiotonic, carminative, antiasthmatic, aphrodisiac, astringent remedy, and has been found effective against diarrhea, dysentery, gout, rheumatism, paralysis, and parasites, and it has been beneficial for skin diseases [9]. The Aquilaria species was previously found to possess antidepressant [10,11], antineuroinflammatory [12], analgesic, antiinflammatory [13], antioxidant, antibacterial [6], antihyperglycemic in vivo [14], and laxative activity in vivo [15].

Aquilaria malaccensis Lam. (syn. Aquilaria agallocha Roxb.) (Thymelaeaceae) is a tropical tree native to Malaysia, locally known as "Karas". It is distributed in the rainforests of Indonesia, Thailand, Cambodia, Laos, Malaysia, Philippines, and India [16]. The alcoholic extract of $A$. malaccensis stems and bark exhibited cardiotonic activity [17], and cytotoxicity against Eagle's carcinoma of the nasopharynx and P-388 lymphocytic leukemia cells in vitro [18]. The aqueous extract showed antitrypanosomal [19], antibacterial [20], and antiallergic activity in vitro and in vivo [7]. The study on the composition of agarwood from A. malaccensis utilizing gas chromatography-mass spectrometry (GC-MS) revealed the presence of chromones, aromatic compounds, sesquiterpenes, monoterpenes, steroids and fatty acids [21]. In a previous phytochemical investigation, feruryl glyceride and phorbol ester were isolated from A. malaccensis bark [18].

However, there was no investigation reporting on composition and bioactivity of $A$. malaccensis seeds (AMS).

In the current study, we investigated antiallergic, antiinflammatory, and cytotoxic activities of AMS extract and its fractions. Within a project of continuous screening for active natural products, AMS showed strong antiallergic effect with an $\mathrm{IC}_{50}$ value less than $1 \mu \mathrm{g} / \mathrm{mL}$ in degranulation assay. Therefore, a phytochemical investigation of AMS was undertaken through a bioactivity-guided fractionation approach. The active components of the most active fraction were further defined as a mixture of phorbol esters, and, moreover, the new active phorbol ester possessing polyunsaturated fatty acid (1) was isolated.

\section{Results and Discussion}

\subsection{Antiallergic, Antiinflammatory, Cytotoxic Effects of A. malaccensis Seeds (AMS)}

The preliminary bioactivity screening of AMS ethanolic extract (A-EtOH) showed potent antiallergic $\left(\mathrm{IC}_{50} 0.92\right.$ and $3.9 \mu \mathrm{g} / \mathrm{mL}$ in $\mathrm{A} 23187$ and antigen-induced $\beta$-hexosaminidase assay, respectively) (Table 1), and antiinflammatory activities $(90.1 \%$ and $85.3 \%$ inhibition of superoxide generation and elastase release at $10 \mu \mathrm{g} / \mathrm{mL}$, respectively) (Table 2). All partitioned fractions except water layer displayed significant antiallergic and antiinflammatory activities (A-BuOH, A-EtOAc, A-Hexane, A-MeOH). 
Table 1. Antiallergic activity of Aquilaria malaccensis seeds extracts, fractions and aquimavitalin (1).

\begin{tabular}{|c|c|c|c|c|c|c|}
\hline \multirow{2}{*}{ Sample } & \multirow{2}{*}{$\begin{array}{c}\text { Viability, RBL-2H3 } \\
\begin{array}{c}\mathrm{IC}_{50}(\mu \mathrm{g} / \mathrm{mL})^{\mathrm{b}} \\
(\% \text { Viability at } 100 \mu \mathrm{g} / \mathrm{mL})\end{array}\end{array}$} & \multicolumn{4}{|c|}{ Inhibition of $\beta$-Hexosaminidase Release, Degranulation Assay, RBL-2H3 Cells a } & \multirow{2}{*}{$\begin{array}{c}\begin{array}{c}\text { Inhibitory Effect on } \\
\text { Enzyme }\end{array} \\
\beta \text {-Hexosaminidase }(\%)\end{array}$} \\
\hline & & $\begin{array}{l}\text { A23187-Induced } \\
\text { IC }_{50}(\mu \mathrm{g} / \mathrm{mL})^{\mathrm{b}}\end{array}$ & Therapeutical Index ${ }^{c}$ & $\begin{array}{l}\text { Antigen-Induced } \\
\mathrm{IC}_{50}(\mu \mathrm{g} / \mathrm{mL})^{\mathrm{b}}\end{array}$ & Therapeutical Index ${ }^{c}$ & \\
\hline A-EtOH & $>100(86.0 \%)$ & 0.92 & $>109.0$ & 3.9 & $>25.7$ & $12.7 \pm 4.2(100 \mu \mathrm{g} / \mathrm{mL})$ \\
\hline $\mathrm{A}-\mathrm{BuOH}$ & $>100(93.3 \%)$ & 1.1 & $>92.1$ & 6.0 & $>16.7$ & $7.3 \pm 5.5(100 \mu \mathrm{g} / \mathrm{mL})$ \\
\hline A-Water & $>100(94.0 \%)$ & - & - & - & - & $\mathrm{N} / \mathrm{A}^{\mathrm{e}}$ \\
\hline A-EtOAc & $>100(90.3 \%)$ & 0.56 & $>177.9$ & 0.86 & $>116.8$ & $13.3 \pm 2.1(100 \mu \mathrm{g} / \mathrm{mL})$ \\
\hline A-Hexane & $>100(95.3 \%)$ & 0.83 & $>120.1$ & 5.1 & $>19.5$ & $13.7 \pm 2.5(100 \mu \mathrm{g} / \mathrm{mL})$ \\
\hline $\mathrm{A}-\mathrm{MeOH}$ & 96.8 & 0.0089 & $10,910.9$ & 0.069 & 1405.2 & $5.3 \pm 3.2(10 \mu \mathrm{g} / \mathrm{mL})$ \\
\hline AM4 & 98.0 & 0.0034 & $28,677.6$ & 0.0065 & $15,098.4$ & $4.7 \pm 4.0(10 \mu \mathrm{g} / \mathrm{mL})$ \\
\hline AM4-4 & 70.6 & $4.8 \times 10^{-5}$ & $1,477,328.2$ & $6.8 \times 10^{-4}$ & $103,776.5$ & $\mathrm{~N} / \mathrm{A}^{\mathrm{e}}$ \\
\hline AM4-4-7 & 73.8 & $7.4 \times 10^{-4}$ & $99,680.2$ & 0.0065 & $11,309.9$ & $\mathrm{~N} / \mathrm{A}^{\mathrm{e}}$ \\
\hline AM4-4-8 & 73.4 & $7.6 \times 10^{-6}$ & $9,645,374.3$ & $8.0 \times 10^{-5}$ & $917,440.9$ & $\mathrm{~N} / \mathrm{A}^{\mathrm{e}}$ \\
\hline quimavitalin (1) & 71.5 & $0.0010(0.0017 \mu \mathrm{M})$ & $71,538.5$ & $0.0068(0.011 \mu \mathrm{M})$ & $10,550.2$ & $4.3 \pm 4.5(10 \mu \mathrm{g} / \mathrm{mL})$ \\
\hline
\end{tabular}

a Dexamethasone $(10 \mathrm{nM})$ inhibited $54.0 \% \pm 4.0 \%$ of A23187-induced $\beta$-hexosaminidase release and $54.3 \% \pm 7.2 \%$ of antigen-induced $\beta$-hexosaminidase release;

${ }^{b} \mathrm{IC}_{50}$ values express the concentration of the sample required to inhibit cell growth or degranulation by $50 \%$; ${ }^{\mathrm{c}}$ Therapeutic index was calculated by dividing IC $\mathrm{C}_{50}$ value from 3-(4,5-dimethylthiazol-2-yl)-2,5-diphenyltetrazolium bromide (MTT) viability assay with corresponding $\mathrm{IC}_{50}$ value from degranulation assay; ${ }^{\mathrm{d}}$ Results are presented as mean $\pm \mathrm{SD}(n=3) ;{ }^{\mathrm{e}} \mathrm{N} / \mathrm{A}$, not applicable; A-EtOH: crude ethanolic extract of Aquilaria malaccensis seeds; A-BuOH: n-butanol layer from Aquilaria malaccensis seeds; A-Water: water layer from Aquilaria malaccensis seeds; A-EtOAc: ethyl acetate layer from Aquilaria malaccensis seeds; A-Hexane: n-hexane layer from Aquilaria malaccensis seeds; A-MeOH: methanol layer from Aquilaria malaccensis seeds, AM: subfractions of methanol layer from Aquilaria malaccensis seeds. 
Table 2. Antiinflammatory effects of $A$. malaccensis seeds extracts on superoxide anion generation and elastase release in $\mathrm{fMLP} / \mathrm{CB}-i n d u c e d$ human neutrophils ${ }^{\mathrm{a}}$.

\begin{tabular}{ccccc}
\hline Sample & \multicolumn{2}{c}{ Superoxide Anion Generation (Inh \%) } & \multicolumn{2}{c}{ Elastase Release (Inh \%) } \\
\hline A-EtOH & $90.1 \pm 5.3$ & $* *$ & $85.3 \pm 0.8$ & $* *$ \\
A-BuOH & $93.9 \pm 8.3$ & $* *$ & $77.6 \pm 2.4$ & $* *$ \\
A-Water & $11.4 \pm 1.6$ & $*$ & $2.7 \pm 4.1$ & - \\
A-EtOAc & $94.8 \pm 5.6$ & $* *$ & $85.4 \pm 1.8$ & $* *$ \\
A-Hexane & $103.4 \pm 1.8$ & $* *$ & $80.2 \pm 4.0$ & $* *$ \\
A-MeOH & $96.5 \pm 8.0$ & $* *$ & $90.4 \pm 6.0$ & $* *$ \\
AM1 & $54.5 \pm 5.7$ & $* *$ & $99.2 \pm 2.3$ & $* *$ \\
AM2 & $68.7 \pm 5.0$ & $* *$ & $47.5 \pm 5.3$ & $* *$ \\
AM3 & $105.9 \pm 3.4$ & $* *$ & $86.8 \pm 2.0$ & $* *$ \\
AM4 & $100.7 \pm 8.1$ & $* *$ & $70.9 \pm 1.0$ & $* *$ \\
AM5 & $102.6 \pm 1.5$ & $* *$ & $93.5 \pm 3.7$ & $* *$ \\
AM6 & $102.4 \pm 2.0$ & $* *$ & $99.3 \pm 2.3$ & $* *$ \\
\hline
\end{tabular}

a Percentage of inhibition (Inh \%) at $10 \mu \mathrm{g} / \mathrm{mL}$ concentration; results are presented as mean \pm SEM $(n=3-4)$; ${ }^{*} p<0.05,{ }^{* *} p<0.001$ compared with the control value (formyl-methionyl-leucyl-phenylalanine/cytochalasin B, fMLP/CB).

The effects of the AMS samples on degranulation in both A23187- and antigen-induced $\beta$-hexosaminidase assays were dose-dependent (Tables S1 and S2). To clarify that antiallergic activity of the samples was due to inhibition of $\beta$-hexosaminidase release, and not false positive as a result of direct inhibition of $\beta$-hexosaminidase enzymatic activity [22], the enzyme was extracted and tested with the active samples. None of the samples inhibited the enzymatic activity of $\beta$-hexosaminidase (Table 1).

As the methanol layer proved the best antiallergic activity $\left(\mathrm{IC}_{50} 0.0089\right.$ and $0.069 \mu \mathrm{g} / \mathrm{mL}$ in A23187 and antigen-induced degranulation assay, respectively), it was further separated using silica gel column chromatography to yield six fractions, AM1-AM6 (subfractions of methanol layer from Aquilaria malaccensis seeds). Among them, fraction AM4 showed the most remarkable antiallergic activity inhibiting $\beta$-hexosaminidase release from mast cells induced by either A23187 $\left(\mathrm{IC}_{50} 0.0034 \mu \mathrm{g} / \mathrm{mL}\right.$ ) or antigen ( $\mathrm{IC}_{50}$ value $0.0065 \mu \mathrm{g} / \mathrm{mL}$ ).

In cytotoxicity assay against a panel of three cancer cell lines (human hepatocellular carcinoma cells HepG2, human breast adenocarcinoma cells A549, and human lung adenocarcinoma cells MDA-MB231), only some of the AMS fractions showed cytotoxic activities at a $20-\mu \mathrm{g} / \mathrm{mL}$ level (Table 3) (A-BuOH 57.1\% against A549, AM4 56.5\% against MDA-MB231 and 79.3\% against A549, AM6 56.0\% against MDA-MB231 cell line). Moreover, considering weak cytotoxicity of AMS towards RBL-2H3 cells, the antiallergic active fraction AM4 exerted therapeutic index up to 28,000. To further rule out the possibility that AM4 causes direct mast cell activation, we examined the capacity of AM4 to elicit degranulation by itself. Results showed that the AM4 treatments did not cause significant degranulation as compared with untreated control (Figure 1). These data implied that AM4 is the best target for further phytochemical analysis.

\subsection{Chemical Analysis and Bioactivity-Guided Fractionation}

Following bioactivity-guided fractionation of the active fractions, the AM4 was further separated, yielding several active fractions, AM4-3, AM4-4, and AM4-5 (Tables S1 and S2).

AM4-4 (IC $504.8 \times 10^{-5} \mu \mathrm{g} / \mathrm{mL}$, therapeutic index 1477328, A23187-induced; and $\mathrm{IC}_{50} 6.8 \times 10^{-4} \mu \mathrm{g} / \mathrm{mL}$, therapeutic index 103776, antigen-induced $\beta$-hexosaminidase assay) afforded the most active fraction AM4-4-8 $\left(\mathrm{IC}_{50} 7.6 \times 10^{-6} \mu \mathrm{g} / \mathrm{mL}\right.$, therapeutic index 9645374, A23187-induced; and $\mathrm{IC}_{50} 8.0 \times 10^{-5} \mathrm{\mu g} / \mathrm{mL}$, therapeutic index 917440, antigen-induced degranulation assay), and a new compound, aquimavitalin (1) ( $\mathrm{IC}_{50}$ values of $0.0017 \mu \mathrm{M}$, therapeutic index 71,538, A23187-induced; and $\mathrm{IC}_{50} 0.011 \mu \mathrm{M}$, therapeutic index 10,550, antigen-induced degranulation assay) (Figure 2). 
Table 3. Cytotoxic screening of $A$. malaccensis seeds extracts on cancer cell lines ${ }^{\text {a }}$.

\begin{tabular}{cccc}
\hline Sample & HepG2 $^{\mathbf{b}}$ & MDA-MB231 $^{\mathbf{c}}$ & A549 $^{\mathbf{d}}$ \\
\hline A-EtOH & 16.0 & 37.2 & 29.7 \\
A-BuOH & 4.2 & 34.4 & 57.1 \\
A-Water & -9.3 & 6.8 & 13.3 \\
A-EtOAc & 1.5 & 41.2 & 23.5 \\
A-Hexane & 25.1 & 42.5 & 16.8 \\
A-MeOH & -0.8 & 30.3 & 32.7 \\
AM1 & 8.1 & 1.7 & -12.6 \\
AM2 & 2.4 & 11.5 & 19.8 \\
AM3 & 25.5 & 46.3 & 39.5 \\
AM4 & 23.4 & 56.5 & 79.3 \\
AM5 & 7.9 & 39.9 & 29.2 \\
AM6 & 5.3 & 56.0 & 39.5 \\
doxorubicin & 91.3 & 97.7 & 98.0 \\
\hline
\end{tabular}

a Percentage of inhibition (\%) at $20 \mu \mathrm{g} / \mathrm{mL}$ concentration $(n=1) ;{ }^{\mathrm{b}}$ Hep-G2: human hepatocellular carcinoma cells; ${ }^{\mathrm{c}}$ MDA-MB231: human breast adenocarcinoma cells; ${ }^{\mathrm{d}}$ A549: human lung adenocarcinoma cells; ${ }^{\mathrm{e}}$ Positive control $(2 \mu \mathrm{g} / \mathrm{mL})$.

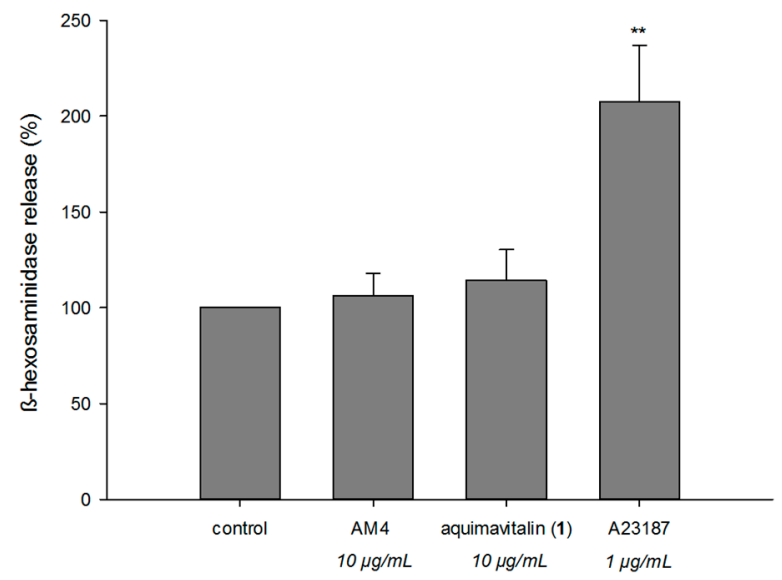

Figure 1. Activity of phorbol ester-rich fraction (AM4) and aquimavitalin (1) on stimulant-free degranulation in RBL-2H3 cells. The RBL-2H3 cells were treated with AM4 $(10 \mu \mathrm{g} / \mathrm{mL})$ and aquimavitalin $(10 \mu \mathrm{g} / \mathrm{mL})$ for $10 \mathrm{~h}$. Tyrode's buffer supplemented with glucose, bovine serum albumin (BSA) and glutamine was used as a medium. A23187 $(1 \mu \mathrm{M})$ was used as a positive control. Data are expressed as mean $\pm \mathrm{SD}(\mathrm{n}=3)$. ${ }^{* *} p<0.001$ compared with the control value.

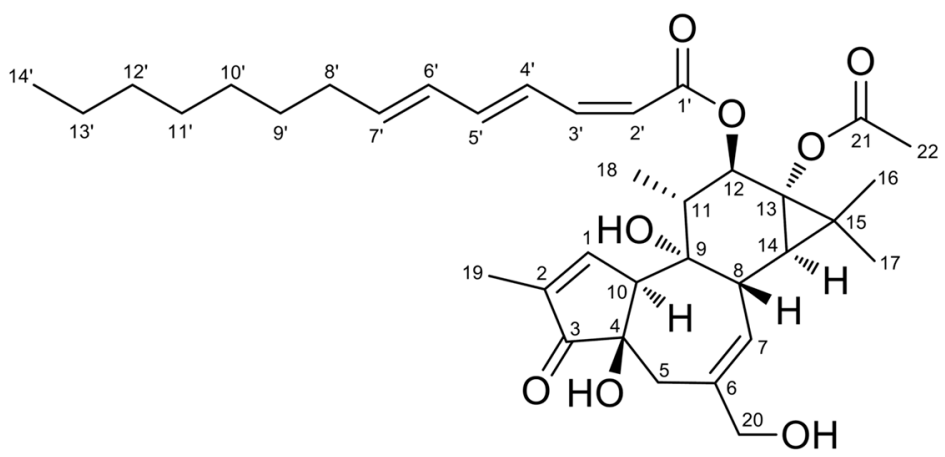

Figure 2. Structure of aquimavitalin (1). 
According to ${ }^{1} \mathrm{H}$ NMR of the crude $(\mathrm{A}-\mathrm{EtOH})$, methanolic (A-MeOH) and the subsequent active fractions (AM4 and AM4-4) (Figure S1), we found the proportional relationship of the antiallergic activity with the increase in signals typical for phorbol diterpenes $\left(\delta_{\mathrm{H}} 7.5, \mathrm{H}-1 ; \delta_{\mathrm{H}} 5.6, \mathrm{H}-7\right.$; $\left.\delta_{\mathrm{H}} 4.0, \mathrm{H}-20\right)$.

\subsection{Structure Elucidation of Aquimavitalin (1)}

Compound 1 (Figures S2-S8) was isolated as a colorless oil. It was assigned the molecular formula $\mathrm{C}_{36} \mathrm{H}_{50} \mathrm{O}_{8} \mathrm{Na}$, according to high-resolution electrospray ionization mass spectrometry (HR-ESIMS) $\left(m / z 633.33980[\mathrm{M}+\mathrm{Na}]^{+}\right.$, calcd. 633.33979), indicating 12 degrees of unsaturation. Its IR spectrum revealed the presence of hydroxyl $\left(3413 \mathrm{~cm}^{-1}\right)$, carbonyl $\left(1710 \mathrm{~cm}^{-1}\right)$ and olefinic $\left(1615 \mathrm{~cm}^{-1}\right)$ functionalities.

The NMR data of compound $1\left({ }^{1} \mathrm{H},{ }^{13} \mathrm{C}\right.$ and heteronuclear multiple quantum coherence, HMQC, Table 4) confirmed the presence of $\alpha, \beta$-unsaturated carbonyl $\left(\delta_{\mathrm{H}} 7.57, \mathrm{~s}, \mathrm{H}-1, \delta_{\mathrm{C}} 160.8\right.$, $\left.\mathrm{C}-1 ; \delta_{\mathrm{C}} 132.8, \mathrm{C}-2 ; \delta_{\mathrm{C}} 209.3, \mathrm{C}-3\right)$, trisubstituted double bond $\left(\delta_{\mathrm{H}} 5.68\right.$, brs, H-7, $\delta_{\mathrm{C}} 129.1, \mathrm{C}-7$; $\left.\delta_{\mathrm{C}} 140.6, \mathrm{C}-6\right)$, oxygenated methylene $\left(\delta_{\mathrm{H}} 3.95, \mathrm{~d}, J=12.8 \mathrm{~Hz}, 4.02, \mathrm{~d}, J=12.8 \mathrm{~Hz}, \mathrm{H}-20, \delta_{\mathrm{C}}\right.$ $67.9, \mathrm{C}-20)$, oxygenated methane $\left(\delta_{\mathrm{H}} 5.43, \mathrm{~d}, J=10.4 \mathrm{~Hz}, \mathrm{H}-12, \delta_{\mathrm{C}} 75.9, \mathrm{C}-12\right)$, four methyls, a methylene and four methines. Furthermore, signals for acetyl group $\left(\delta_{\mathrm{H}} 2.10, \mathrm{~s}, \mathrm{H}-22, \delta_{\mathrm{C}} 21.1\right.$, $\left.\mathrm{C}-22 ; \delta_{\mathrm{C}} 173.9, \mathrm{C}-21\right)$ and fatty acid moiety including six olefinic protons, six methylenes and terminal methyl group were detected. The ${ }^{1} \mathrm{H}$ NMR data was closely related to known compound 12-O-(2Z,4E,6E)-deca-2,4,6-trienoylphorbol-13-acetate [18] except of the length of the fatty acid moiety (Table S3).

Table 4. $1 \mathrm{D}$ and $2 \mathrm{D}$ NMR data of aquimavitalin (1) in $\mathrm{CDCl}_{3}{ }^{\mathrm{a}}$.

\begin{tabular}{|c|c|c|c|c|c|}
\hline Position & $\delta_{\mathrm{H}}$, Multiplicity $(J$ in $\mathrm{Hz})$ & $\delta_{\mathrm{C}}$, Type & $\operatorname{COSY}\left({ }^{1} \mathrm{H}-{ }^{1} \mathbf{H}\right)$ & HМBC $\left({ }^{1} \mathrm{H}-{ }^{13} \mathrm{C}\right)$ & NOESY $\left({ }^{1} \mathbf{H}-{ }^{1} \mathbf{H}\right)$ \\
\hline 1 & $7.57(\mathrm{~s})$ & $160.8 \mathrm{CH}$ & 10,19 & 4,10 & 18 \\
\hline 2 & - & $132.8 \mathrm{C}$ & - & - & - \\
\hline 3 & - & $209.3 \mathrm{C}$ & - & - & - \\
\hline 4 & - & $73.6 \mathrm{C}$ & - & - & - \\
\hline $5 \alpha$ & $2.48(\mathrm{~d}, J=18.8)$ & $38.3 \mathrm{CH}_{2}$ & 7 & $4,6,7$ & 5,20 \\
\hline $5 \beta$ & $2.58(\mathrm{~d}, J=18.8)$ & - & - & - & - \\
\hline 6 & - & $140.6 \mathrm{C}$ & - & - & _- \\
\hline 7 & 5.68 (brs) & $129.1 \mathrm{CH}$ & 5,8 & 14,20 & 14,20 \\
\hline 8 & $3.26(\mathrm{t}, J=5.2)$ & $38.8 \mathrm{CH}$ & 7,14 & $6,14,15$ & 11,17 \\
\hline 9 & - & $78.4 \mathrm{C}$ & - & - & - \\
\hline 10 & 3.22 (brs) & $55.9 \mathrm{CH}$ & 1,19 & - & - \\
\hline 11 & $2.13(\mathrm{~m})$ & $43.0 \mathrm{CH}$ & 12,18 & _- & 17,18 \\
\hline 12 & $5.43(\mathrm{~d}, J=10.4)$ & $75.9 \mathrm{CH}$ & 11 & $11,13,15,18,1^{\prime}$ & 18 \\
\hline 13 & - & $65.7 \mathrm{C}$ & - & - & - \\
\hline 14 & $1.08(\mathrm{~d}, J=5.2)$ & $36.1 \mathrm{CH}$ & 8 & $7,13,15,16$ & - \\
\hline 15 & - & $25.6 \mathrm{C}$ & - & - & - \\
\hline 16 & $1.19(\mathrm{~s})$ & $23.8 \mathrm{CH}_{3}$ & - & $13,14,15,17$ & - \\
\hline 17 & $1.24(\mathrm{~s})$ & $16.7 \mathrm{CH}_{3}$ & - & $13,14,15,16$ & - \\
\hline 18 & 0.88 (d, overlap) & $14.0 \mathrm{CH}_{3}$ & 11 & $9,11,12$ & _- \\
\hline 19 & 1.73 (brs) & $10.0 \mathrm{CH}_{3}$ & 1,10 & $1,2,3$ & - \\
\hline $20 \mathrm{a}$ & $4.02(\mathrm{~d}, J=12.8)$ & $67.9 \mathrm{CH}_{2}$ & - & $5,6,7$ & - \\
\hline $20 \mathrm{~b}$ & $3.95(\mathrm{~d}, J=12.8)$ & - & - & - & - \\
\hline 21 & - & $173.9 \mathrm{C}$ & - & 22 & - \\
\hline 22 & $2.10(\mathrm{~s})$ & $21.1 \mathrm{CH}_{3}$ & - & - & - \\
\hline $1^{\prime}$ & - & $166.3 \mathrm{C}$ & - & - & - \\
\hline $2^{\prime}$ & $5.57(\mathrm{~d}, J=11.2)$ & $115.6 \mathrm{CH}$ & $3^{\prime}$ & _- & $3^{\prime}$ \\
\hline $3^{\prime}$ & $6.59(\mathrm{t}, J=11.6)$ & $145.6 \mathrm{CH}$ & $2^{\prime}, 4^{\prime}$ & $1^{\prime}, 5^{\prime}$ & - \\
\hline $4^{\prime}$ & $7.39(\mathrm{dd}, J=15.2$ and 11.6$)$ & $126.5 \mathrm{CH}$ & $3^{\prime}, 5^{\prime}$ & - & $6^{\prime}$ \\
\hline $5^{\prime}$ & $6.46(\mathrm{dd}, J=14.8$ and 10.4$)$ & $142.4 \mathrm{CH}$ & $4^{\prime}, 6^{\prime}$ & - & $7^{\prime}$ \\
\hline $6^{\prime}$ & $6.20(\mathrm{dd}, J=15.2$ and 10.8$)$ & $130.1 \mathrm{CH}$ & $5^{\prime}, 7^{\prime}$ & _- & - \\
\hline $7^{\prime}$ & $5.92(\mathrm{dt}, J=15.2$ and 7.2$)$ & $141.0 \mathrm{CH}$ & $6^{\prime}, 8^{\prime}$ & - & - \\
\hline $8^{\prime}$ & $2.13(\mathrm{~m})$ & $33.0 \mathrm{CH}_{2}$ & $7^{\prime}, 9^{\prime}$ & $6^{\prime}, 7^{\prime}, 9^{\prime}$ & $9^{\prime}$ \\
\hline $9^{\prime}$ & $1.38(\mathrm{~m})$ & $28.9 \mathrm{CH}_{2}$ & $8^{\prime}$ & $10^{\prime}$ & - \\
\hline $10^{\prime}$ & $1.26-1.28(\mathrm{~m}$, overlap $)$ & $29.1 \mathrm{CH}_{2}$ & - & - & - \\
\hline $11^{\prime}$ & $1.26-1.28$ (m, overlap) & $29.1 \mathrm{CH}_{2}$ & - & - & - \\
\hline $12^{\prime}$ & $1.26-1.28$ (m, overlap) & $31.7 \mathrm{CH}_{2}$ & _- & _- & _- \\
\hline $13^{\prime}$ & $1.26-1.28$ (m, overlap) & $22.6 \mathrm{CH}_{2}$ & - & - & - \\
\hline $14^{\prime}$ & $0.86(\mathrm{t}, J=7.2)$ & $14.4 \mathrm{CH}_{3}$ & - & $12^{\prime}, 13^{\prime}$ & - \\
\hline
\end{tabular}

${ }^{\text {a }}{ }^{1} \mathrm{H}$ and ${ }^{13} \mathrm{C}$ NMR data $(\delta)$ were measured at 400 and $100 \mathrm{MHz}$, respectively; chemical shifts are in ppm; COSY: Correlation spectroscopy; HMBC: Heteronuclear multiple bond correlation spectroscopy; NOESY: Nuclear Overhauser effect spectroscopy. 
The ${ }^{1} \mathrm{H}-{ }^{1} \mathrm{H}$ correlation spectroscopy (COSY) correlations (Figure 3) indicated the presence of C-10/C-1/C-19, C-5/C-7/C-8/C-14, and C-12/C-11/C-18 moieties for backbone, $\mathrm{C}-2^{\prime} / \mathrm{C}-3^{\prime} / \mathrm{C}-4^{\prime} / \mathrm{C}-5^{\prime} / \mathrm{C}-6^{\prime} / \mathrm{C}-7^{\prime} / \mathrm{C}-8^{\prime} / \mathrm{C}-9^{\prime}$ for fatty acid moiety. The COSY correlations together with long-range heteronuclear multiple bond correlation spectroscopy (HMBC) correlations (Figure 3) from H-19/C-1, C-2, C-3; H-1/C-4; H-5/C-4; H-20/C-5, C-6, C-7; H-8/C-6, C-14, C-15; H-12 to C-11, C-13, C-15, C-18; H-18/C-9; H-16 and H-17/ C-13, C-14, C-15 established the tigliane (phorbol) type diterpene backbone of compound $\mathbf{1}[23,24]$.

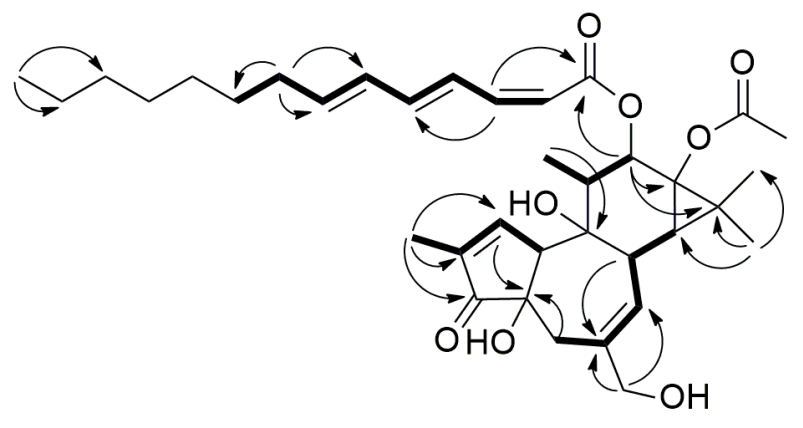

Figure 3. Key ${ }^{1} \mathrm{H}-{ }^{1} \mathrm{H}$ correlation spectroscopy (COSY) (bold) and HMBC (arrow) correlations of aquimavitalin (1).

The relative configuration was assigned by means of nuclear Overhauser effect spectroscopy (NOESY) correlations of $\mathbf{1}$ (Figure 4). The cross-peaks of $\mathrm{H}-8 / \mathrm{H}-11, \mathrm{H}-11 / \mathrm{H}-17$ and $\mathrm{H}-17 / \mathrm{H}-8$ indicated that they are all $\beta$-oriented. Moreover, the correlation between $\mathrm{H}-1 / \mathrm{H} 18 / \mathrm{H}-12$ suggested that the fatty acid moiety is also $\beta$-oriented [23]. Additionally, 1 showed negative specific optical rotation $(-3.8)$ similar to 12-O-(2Z,4E,6E)-deca-2,4,6-trienoylphorbol-13-acetate (-15.3) [18].

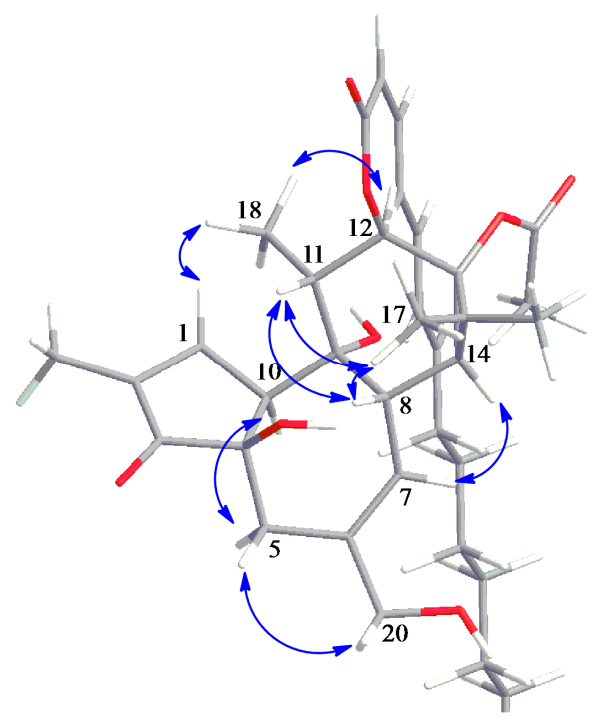

Figure 4. Key NOESY (double-headed arrow) correlations of aquimavitalin (1). Grey color represents carbon, red color oxygen and white color proton.

The fatty acid was identified as $(2 Z, 4 E, 6 E)$-tetradeca-2,4,6-trienoic acid according to $1 \mathrm{D}$ NMR and COSY correlations supported by following HMBC correlations, H-3 $3^{\prime}$ C- $1^{\prime}\left(\delta_{\mathrm{C}} 166.3\right)$, $\mathrm{C}-5^{\prime}\left(\delta_{\mathrm{C}} 142.4\right) ; \mathrm{H}-8^{\prime} / \mathrm{C}-6^{\prime}\left(\delta_{\mathrm{C}} 130.1\right), \mathrm{C}-7^{\prime}\left(\delta_{\mathrm{C}} 141.0\right), \mathrm{C}-9^{\prime}\left(\delta_{\mathrm{C}} 28.9\right) ; \mathrm{H}-9^{\prime} / \mathrm{C}-10^{\prime}\left(\delta_{\mathrm{C}} 29.1\right)$ and $\mathrm{H}-14^{\prime} / \mathrm{C}-12^{\prime}\left(\delta_{\mathrm{C}} 31.7\right), \mathrm{C}-13^{\prime}\left(\delta_{\mathrm{C}} 22.6\right)$. The geometry of the double bonds was assigned by coupling constants in ${ }^{1} \mathrm{H}$ NMR. The NMR data were in agreement with those of $(2 Z, 4 E, 6 E)$-ethyl 
tetradeca-2,4,6-trienoate [25]. The fatty acid moiety was attached to phorbol backbone at C-12 by virtue of HMBC correlation from $\mathrm{H}-12$ to $C-1^{\prime}\left(\delta_{\mathrm{C}} 166.3\right)$. Therefore, compound 1 was identified as $12-O-(2 Z, 4 E, 6 E)$-tetradeca-2,4,6-trienoylphorbol-13-acetate and named as aquimavitalin.

\subsection{Antiallergic Activity of Aquimavitalin (1)}

In degranulation assay, aquimavitalin (1) showed significant $\beta$-hexosaminidase release-inhibitory activity with $\mathrm{IC}_{50}$ values of $0.0017 \mu \mathrm{M}$ (therapeutic index 71,538) using A23187 as an inducer and $0.011 \mu \mathrm{M}$ (therapeutic index 10,550) using antigen as an inducer. Aquimavitalin (1) did not inhibit $\beta$-hexosaminidase enzymatic activity (Table 1), neither trigger the degranulation of unstimulated mast cells (Figure 1). According to our results, phorbol ester-rich fractions (AM4-4, AM4-4-8) showed stronger activity (up to $\mathrm{pg} / \mathrm{mL}$ level) than a pure compound. This phenomenon may be a result of synergistic effects of phorbol esters in the mixture.

In general, phorbol esters, particularly phorbol-12-myristate-13-acetate (PMA), are well-known as irritant, proinflammatory and cocarcinogenic. Nevertheless, phorbol esters were previously reported to exert antiinflammatory, anti-HIV, antiparasitic and anticancer activities [26]. Both free C-20 hydroxy, and C-12 and/or C-13 ester moieties were important for the activities of phorbol esters [26]. Importantly, it was suggested that unsaturation of ester functionality may play a crucial role in bioactivity of phorbols [26,27]. Previously, 12-O-(2Z,4E,6E)-deca-2,4,6-trienoylphorbol-13-acetate, a phorbol ester possessing similar conjugated fatty acid moiety as $\mathbf{1}$, was isolated from A. malaccensis bark and exerted cytotoxic activity in P-388 lymphocytic leukemia cells in vitro [18]. In structure-activity relationship study on phorbol esters containing fatty acids with different level of unsaturation and carbon chain length, phorbol esters carrying conjugated unsaturated fatty acid as acyl group showed irritant but very weak tumor-promoting activities. [27]. This is the first study to report on the antiallergic potential of pure phorbol ester with the therapeutic index up to 71,000. The antiallergic activity of AMS together with identification of its active component provides scientific support for the folk use of A. malaccensis against asthma.

\section{Materials and Methods}

\subsection{General Procedures}

Sephadex LH-20 (Merck KGaA, Darmstadt, Germany), silica gel 60 (Merck KGaA) and Geduran Si 60 (Merck KGaA) were used for column chromatography. TLC plates (Silica Kiesel 60 F254) were from Merck KGaA. Jasco V-530 ultraviolet spectrophotometer (Jasco International Co., Ltd, Tokyo, Japan) was used to measure UV spectra. IR spectra were obtained on an FT-IR-4100 Jasco spectrophotometer (Jasco). Optical rotations were achieved by a Jasco P-2000 digital polarimeter (Jasco). NMR spectra were obtained by JEOL JNM ECS $400 \mathrm{MHz}$. Electrospray ionization mass spectrometry (ESIMS) data were collected on a Waters micromass ZQ mass spectrometer (Waters Corporation, Milford, MA, USA). High-resolution ESIMS data was accomplished by a Bruker APEX II spectrometer (FT-ICR/MS, FTMS) (Bruker Daltonics Inc., Billerica, MA, USA). Dulbecco's modified Eagle's medium (high glucose) powder (DMEM), 3-(4,5-dimethylthiazol-2-yl)-2,5-diphenyltetrazolium bromide (MTT), $p$-nitrophenyl- $N$-acetyl-D-glucosaminide ( $p$-NAG), penicillin and streptomycin, dexamethasone, calcium ionophore A23187, and dimethyl sulfoxide (DMSO) were purchased from Sigma-Aldrich (St. Louis, MO, USA). Fetal bovine serum (FBS) was obtained from Hyclone (Logan, UT, USA). Mouse anti-DNP IgE antibody was a generous gift from Dr. Daniel H. Conrad (Virginia Commonwealth University, Richmond, VA, USA).

\subsection{Plant Material}

The seeds of $A$. malaccensis were obtained from Hsue-Yin Hsu, Tzu Chi University, Hualien, Taiwan, in November 2014. The plant material was identified by Hsue-Yin Hsu, Department of Life Sciences, Tzu Chi University, Hualien, Taiwan. A voucher specimen (code no. KMU-AMS 1) was 
deposited in the Graduate Institute of Natural Products, College of Pharmacy, Kaohsiung Medical University, Kaohsiung, Taiwan.

\subsection{Extraction and Isolation}

Air-dried and powdered seeds of $A$. malaccensis ( $462 \mathrm{~g}$ ) were extracted with $90 \% \mathrm{EtOH}$ at room temperature $(3 \times 5 \mathrm{~L})$ and then concentrated under reduced pressure. The combined extracts were concentrated and obtained crude ethanolic extract (A-EtOH, $27.7 \mathrm{~g})$ was suspended in water and partitioned with ethyl acetate $(3 \times 1 \mathrm{~L})$. The water layer was partitioned with $n$-butanol $(3 \times 1 \mathrm{~L})$ to yield water layer (A-Water, $1654.0 \mathrm{~g}$ ) and $n$-butanol layer (A-BuOH, 398.2 g). The EtOAc layer (A-EtOAc, $25.6 \mathrm{~g}$ ) was further partitioned with $n$-hexane and $90 \%$ aqueous $\mathrm{MeOH}$ to obtain $n$-hexane layer (A-Hexane, 7.1 g) and $\mathrm{MeOH}$ layer (A-MeOH, $16.2 \mathrm{~g})$. The $\mathrm{MeOH}$ layer $(\mathrm{A}-\mathrm{MeOH})$ was subjected to a column chromatography over silica gel $(23 \mathrm{~cm} \times 4 \mathrm{~cm}$, silica gel $60,0.063-0.200 \mathrm{~mm}$, Merck) under a gradient elution of $n$-hexane $/ \mathrm{CH}_{2} \mathrm{Cl}_{2} / \mathrm{MeOH}$ to yield six fractions (AM1, 6:3:1; AM2, 6:4:1; AM3, 6:6:1; AM4, 6:8:1; AM5, 6:10:1 and AM6, 6:10:2). Following bioactivity data, fraction AM4 (3212.0 g) was further fractionated over a Sephadex LH-20 column $\left(\mathrm{CH}_{2} \mathrm{Cl}_{2} / \mathrm{MeOH}, 1: 1\right)$ to obtain eight sub-fractions (AM4-1 to AM4-8). Fraction AM4-3 (762.0 mg) was subjected to column chramtography $(17 \mathrm{~cm} \times 4 \mathrm{~cm}$, Geduran Si 60, 0.040-0.063 mm, Merck) under gradient elution of EtOAc/n-hexane (from 1:10 to 4:1) yielding 15 fractions. Fraction AM4-4 (173.7 mg) was further separated by column chromatography on silica gel (30 cm $\times 1.5 \mathrm{~cm}$, Geduran Si 60, 0.040-0.063 mm, Merck) under gradient elution of EtOAc/ $n$-hexane (from 1:15 to 4:1) to obtain fraction AM4-4-7 (37.6 mg) and AM4-4-8 (6.8 mg) and aquimavitalin (1) $(43.9 \mathrm{mg})$ together with other 8 subfractions. The yield of aquimavitalin (1) was $0.0095 \%$ from dry plant material, $0.16 \%$ from crude EtOH extract.

\subsection{Experimental Data of Aquimavitalin (1)}

Aquimavitalin (1): Colourless oil; $[\alpha]_{\mathrm{D}}^{25}-3.75$ (c 0.067, $\left.\mathrm{CHCl}_{3}\right)$; UV (MeOH) $\lambda_{\max }(\log \varepsilon) 303$ (2.78), 233 (2.75) nm; IR (neat) $v_{\max } 3413,2965,2922,1710,1615,1377,1258,1092,802 ;{ }^{1} \mathrm{H} \mathrm{NMR}\left(\mathrm{CDCl}_{3}\right.$, $400 \mathrm{MHz})$ and ${ }^{13} \mathrm{C} \mathrm{NMR}\left(\mathrm{CDCl}_{3}, 100 \mathrm{MHz}\right)$ : see Table 4; ESIMS found $\mathrm{m} / \mathrm{z} 611.3[\mathrm{M}+\mathrm{H}]^{+}$and 633.3 $[\mathrm{M}+\mathrm{Na}]^{+}$; HR-ESIMS found (m/z $633.33980[\mathrm{M}+\mathrm{Na}]^{+}$, (calcd. for $\mathrm{C}_{36} \mathrm{H}_{50} \mathrm{O}_{8} \mathrm{Na}$ : 633.33979).

\subsection{Cell Culture}

The mucosal mast cell-derived rat basophilic leukemia (RBL-2H3) cell line was purchased from the Bioresource Collection and Research Center (Hsin-Chu, Taiwan). Cells were grown in DMEM medium supplemented with $10 \%$ FBS and $100 \mathrm{U} / \mathrm{mL}$ penicillin plus $100 \mathrm{\mu g} / \mathrm{mL}$ streptomycin. Cells were cultured in $10 \mathrm{~cm}$ cell culture dishes at $37^{\circ} \mathrm{C}$ in a humidified chamber with $5 \% \mathrm{CO}_{2}$ in air.

\subsection{Cell Viability Assay}

A methylthiazol tetrazolium (MTT) assay was used to measure the potential toxic effects of the samples on RBL-2H3 cells [28]. Briefly, RBL-2H3 cells $\left(2 \times 10^{4}\right.$ cells / well $)$ were seeded in a 96-well plate overnight and treated with various concentrations of samples $(10-100 \mu \mathrm{g} / \mathrm{mL})$ for $24 \mathrm{~h}$. MTT solution $(0.5 \mathrm{mg} / \mathrm{mL})$ was added to the wells $(80 \mu \mathrm{L}$ per well) and incubated for $1 \mathrm{~h}$. The formed formazan crystals were dissolved in DMSO $(80 \mu \mathrm{L})$. The absorbance at $595 \mathrm{~nm}$ was measured using microplate reader (Multiskan Ascent, Thermo Scientific, Waltham, MA, USA). The degree of cell viability of each sample was calculated as the percentage of control value (untreated cells). The maximal tolerated dose of DMSO was $0.5 \%$. All experiments were repeated at least two times.

\subsection{Degranulation $\beta$-Hexosaminidase Assay Induced by A23187 or Antigen}

The degree of A23187- and antigen-induced degranulation in RBL-2H3 cells was determined by a $\beta$-hexosaminidase release assay as described previously [28,29] with following modifications. RBL-2H3 cells were seeded in a 96-well plate $\left(2 \times 10^{4}\right.$ cells/well $)$ for A23187-induced and in 48-well plate 
$\left(3 \times 10^{4}\right.$ cells /well) for antigen-induced experiment. Cells were treated with various concentrations of the samples for $20 \mathrm{~h}$. Dexamethasone $(10 \mathrm{nM})$ was used as a positive control. The cells for the antigen-induced experiment were first sensitized with anti-DNP $\operatorname{IgE}(5 \mu \mathrm{g} / \mathrm{mL})$ for at least $2 \mathrm{~h}$. After thorough washing by pre-warmed Tyrode's buffer $\left(135 \mathrm{mM} \mathrm{NaCl}, 5 \mathrm{mM} \mathrm{KCl}, 1.8 \mathrm{mM} \mathrm{CaCl}_{2}\right.$, $1.0 \mathrm{mM} \mathrm{MgCl} 2,5.6 \mathrm{mM}$ glucose, $20 \mathrm{mM}$ HEPES at $\mathrm{pH} 7.4$ ), the cells were stimulated by either calcium ionophore A23187 $(1 \mu \mathrm{M})$ or antigen DNP-BSA $(100 \mathrm{ng} / \mathrm{mL})$ in Tyrode's buffer for $1 \mathrm{~h}$. Unstimulated cells were either lysed with $0.5 \%$ Triton X-100 solution for the total amount of $\beta$-hexosaminidase release or left untreated for spontaneous release of $\beta$-hexosaminidase. Then aliquots of supernatants $(50 \mu \mathrm{L})$ were incubated with equal volume of $1 \mu \mathrm{M}$ of p-NAG $(50 \mu \mathrm{L})$ prepared in $0.1 \mathrm{M}$ citrate buffer ( $\mathrm{pH}$ 4.5) serving as a substrate for the released $\beta$-hexosaminidase. After $1 \mathrm{~h}$ of incubation at $37^{\circ} \mathrm{C}$, the reaction was quenched by the addition of $100 \mu \mathrm{L}$ of stop buffer $\left(0.1 \mathrm{M} \mathrm{Na}_{2} / \mathrm{NaHCO}_{3}, \mathrm{pH} 10.0\right)$. Absorbance was measured at $405 \mathrm{~nm}$ on a microplate reader (Multiskan Ascent, Thermo Scientific). The inhibition percentage of $\beta$-hexosaminidase release was calculated as the percentage of control value (untreated stimulated cells). The maximal tolerated dose of DMSO was $0.5 \%$. All experiments were repeated three times.

\subsection{Effect on Enzymatic Activity of $\beta$-Hexosaminidase}

To test the possible effect of the sample on enzymatic activity, following assay was performed. The cell suspension $\left(2 \times 10^{6}\right.$ cells $)$ in $2 \mathrm{~mL}$ of Tyrode's buffer was sonicated for $5 \mathrm{~min}$. The solution was then centrifuged, and the supernatant was diluted with $8 \mathrm{~mL}$ of Tyrode's buffer. The enzyme solution $(45 \mu \mathrm{L})$ and test sample solution $(5 \mu \mathrm{L})$ were transferred into a 96-well microplate and enzyme activity was examined as described above (Section 3.7). All experiments were repeated three times.

\subsection{Direct Degranulation $\beta$-Hexosaminidase Assay Induced by the Sample}

The degree of $\beta$-hexosaminidase release triggered by the sample in RBL-2H3 cells was determined by a modified $\beta$-hexosaminidase release assay. Briefly, RBL-2H3 cells $\left(4 \times 10^{4}\right.$ cells $/$ well $)$ were seeded in a 48-well plate and treated with the samples for $10 \mathrm{~h}$. Tyrode's buffer supplemented with $5.6 \mathrm{mM}$ glucose, $2 \mathrm{mg} / \mathrm{mL}$ BSA and $2 \mathrm{mM}$ glutamine was used to prepare the samples and treat the cells. Then, $50 \mu \mathrm{L}$ of supernatants were transferred into a 96-well microplate and examined as described above (Section 3.7). A23187 $(1 \mu \mathrm{M})$ was used as a positive control. All experiments were repeated three times.

\subsection{Preparation of Human Neutrophils}

Human neutrophils from venous blood of healthy, adult volunteers (20-30 years old) were isolated using a standard method of dextran sedimentation prior to centrifugation in a Ficoll-Hypaque gradient and hypotonic lysis of erythrocytes [30]. Purified neutrophils containing $>98 \%$ viable cells, as determined by the trypan-blue exclusion method [31], were resuspended in a $\mathrm{Ca}^{2+}$-free Hank's buffered salt solution (HBSS) at pH 7.4 and were maintained at $4{ }^{\circ} \mathrm{C}$ prior to use.

\subsection{Superoxide Anion Generation Assay and Elastase Release Inhibition Assay}

Neutrophil superoxide anion generation was determined using superoxide dismutase (SOD)-inhibitory cytochrome reduction according to described procedures [32,33]. Degranulation of azurophilic granules was determined by measuring the elastase release as described previously [33]. All experiments were repeated at least three times.

\subsection{Cytotoxic Assay}

MTT assay was used according to the method described before [34]. Briefly, HepG2 $\left(1 \times 10^{4}\right.$ cells), A549 $\left(5 \times 10^{3}\right.$ cells), and MDA-MB-231 $\left(1 \times 10^{4}\right.$ cells $)$ were seeded into 96 -well plates, followed by treatment with the AMS samples at concentration of $20 \mu \mathrm{g} / \mathrm{mL}$. After $72 \mathrm{~h}$, the medium was removed and $100 \mu \mathrm{L}$ of MTT solution $(0.5 \mathrm{mg} / \mathrm{mL})$ was added to each well. The plates were then incubated at 
$37^{\circ} \mathrm{C}$ for $1 \mathrm{~h}$ and then, the MTT dye was detected by the addition of DMSO $(100 \mu \mathrm{L})$. The absorbance was recorded at $550 \mathrm{~nm}$. Doxorubicin was used as a positive control.

\subsection{Statistics}

The results were expressed as mean $\pm \mathrm{SD}$ unless otherwise specified. The $\mathrm{IC}_{50}$ values were calculated using the Microsoft Office (linear function). Statistical significance was calculated by one-way analysis of variance (ANOVA), followed by Dunnett's test (SigmaPlot, Jandel Scientific, San Rafael, CA, USA). Values with ${ }^{*} p<0.05,{ }^{* *} p<0.001$ were considered statistically significant.

\section{Conclusions}

The present investigation revealed bioactive fractions and pure principle from the extract of AMS. It resulted in the isolation of the active pure compound, aquimavitalin (1). The remarkable inhibitory activity of $\mathbf{1}$ on mast cell degranulation with nanomolar $\mathrm{IC}_{50}$ values provides evidence that phorbol ester could possess antiallergic activity.

Moreover, high potency of phorbol esters may shed light on the use of A. malaccensis seeds in the treatment diseases related to allergy. However, further studies are needed to examine the safety of these materials in therapy.

Supplementary Materials: Supplementary materials can be found at http://www.mdpi.com/1422-0067/ 17/3/398/s1.

Acknowledgments: We thank the Center for Research Resources and Development at Kaohsiung Medical University for providing instrumentation support. This work was supported by the grants from Ministry of Science and Technology, Taiwan (NSC 102-2628-B-037-003-MY3, MOST 103-2320-B-037-005-MY2, awarded to Fang-Rong Chang; MOST 105-2911-I-002-302, awarded to Yang-Chang Wu). This study was also supported by Kaohsiung Medical University, Taiwan (Aim for the Top Universities Grant, grant No. KMU-TP104E39, KMU-TP104A26, KMU-M104008), and Ministry of Health and Welfare, Taiwan (MOHW105-TDU-B-212-134007, Health and welfare surcharge of tobacco products).

Author Contributions: Bing-Hung Chen and Fang-Rong Chang conceived and designed the experiments and contributed to the manuscript preparation. Michal Korinek and Vitthal D. Wagh performed the experiments, analyzed the data and wrote the manuscript. Yu-Ming Hsu assisted with the experiments. I-Wen Lo determined the structure. Hsue-Yin Hsu provided the plant material. Tsong-Long Hwang provided anti-inflammatory data. Yuan-Bin Cheng and Yang-Chang Wu revised the manuscript. All the authors read and approved the final manuscript.

Conflicts of Interest: The authors declare no conflict of interest.

\section{Abbreviations}

AMS

A-EtOH

$\mathrm{A}-\mathrm{BuOH}$

A-Water

A-EtOAc

A-Hexane

$\mathrm{A}-\mathrm{MeOH}$

AM

RBL-2H3

HepG2

A549

MDA-MB231

$\mathrm{fMLP} / \mathrm{CB}$
Aquilaria malaccensis seeds

Crude ethanolic extract of Aquilaria malaccensis seeds

n-Butanol layer from Aquilaria malaccensis seeds

Water layer from Aquilaria malaccensis seeds

Ethyl acetate layer from Aquilaria malaccensis seeds

n-Hexane layer from Aquilaria malaccensis seeds

Methanol layer from Aquilaria malaccensis seeds

Subfractions of methanol layer from Aquilaria malaccensis seeds

Rat basophilic leukemia cells

Human hepatocellular carcinoma cells

Human breast adenocarcinoma cells

Human lung adenocarcinoma cells

Formyl-methionyl-leucyl-phenylalanine/cytochalasin B 


\section{References}

1. Julia, V.; Macia, L.; Dombrowicz, D. The impact of diet on asthma and allergic diseases. Nat. Rev. Immunol. 2015, 15, 308-322. [CrossRef] [PubMed]

2. Lian, Q.; Cheng, Y.; Zhong, C.; Wang, F. Inhibition of the IgE-mediated activation of RBL-2H3 cells by TIPP, a novel thymic immunosuppressive pentapeptide. Int. J. Mol. Sci. 2015, 16, 2252-2268. [CrossRef] [PubMed]

3. Dearman, R.J.; Skinner, R.A.; Deakin, N.; Shaw, D.; Kimber, I. Evaluation of an in vitro method for the measurement of specific IgE antibody responses: The rat basophilic leukemia (RBL) cell assay. Toxicology 2005, 206, 195-205. [CrossRef] [PubMed]

4. Zhang, Z.; Wei, J.; Han, X.; Liang, L.; Yang, Y.; Meng, H.; Xu, Y.; Gao, Z. The sesquiterpene biosynthesis and vessel-occlusion formation in stems of Aquilaria sinensis (Lour.) Gilg trees induced by wounding treatments without variation of microbial communities. Int. J. Mol. Sci. 2014, 15, 23589-23603. [CrossRef] [PubMed]

5. Kuo, T.C.-Y.; Chen, C.-H.; Chen, S.-H.; Lu, I.H.; Chu, M.-J.; Huang, L.-C.; Lin, C.-Y.; Chen, C.-Y.; Lo, H.-F.; Jeng, S.-T.; et al. The effect of red light and far-red light conditions on secondary metabolism in agarwood. BMC Plant Biol. 2015, 15. [CrossRef] [PubMed]

6. Kamonwannasit, S.; Nantapong, N.; Kumkrai, P.; Luecha, P.; Kupittayanant, S.; Chudapongse, N. Antibacterial activity of Aquilaria crassna leaf extract against Staphylococcus epidermidis by disruption of cell wall. Ann. Clin. Microbiol. Antimicrob. 2013, 12. [CrossRef] [PubMed]

7. Kim, Y.C.; Lee, E.H.; Lee, Y.M.; Kim, H.K.; Song, B.K.; Lee, E.J.; Kim, H.M. Effect of the aqueous extract of Aquilaria agallocha stems on the immediate hypersensitivity reactions. J. Ethnopharmacol. 1997, 58, 31-38. [CrossRef]

8. Hashim, Y.Z.H.-Y.; Phirdaous, A.; Azura, A. Screening of anticancer activity from agarwood essential oil. Pharmacogn. Res. 2014, 6, 191-194. [CrossRef] [PubMed]

9. Talukdar, A. Gas chromatography-mass spectrometric analysis of the essential oil of eaglewood (Aquilaria agallocha Roxb). Int. J. Pharm. Pharm. Sci. 2014, 6, 629-631.

10. Yang, L.; Qiao, L.; Ji, C.; Xie, D.; Gong, N.-B.; Lu, Y.; Zhang, J.; Dai, J.; Guo, S. Antidepressant abietane diterpenoids from Chinese eaglewood. J. Nat. Prod. 2013, 76, 216-222. [CrossRef] [PubMed]

11. Huong, D.T.L.; Dat, N.T.; Minh, C.V.; Kang, J.S.; Kim, Y.H. Monoamine oxidase inhibitors from Aquilaria Agallocha. Nat. Prod. Sci. USA 2002, 8, 30-33.

12. Huo, H.-X.; Zhu, Z.-X.; Pang, D.-R.; Li, Y.-T.; Huang, Z.; Shi, S.-P.; Zheng, J.; Zhang, Q.; Zhao, Y.-F.; Tu, P.-F.; et al. Anti-neuroinflammatory sesquiterpenes from Chinese eaglewood. Fitoterapia 2015, 106, 115-121. [CrossRef] [PubMed]

13. Zhou, M.; Wang, H.; Suolangjiba; Kou, J.; Yu, B. Antinociceptive and anti-inflammatory activities of Aquilaria sinensis (Lour.) Gilg. leaves extract. J. Ethnopharmacol. 2008, 117, 345-350. [CrossRef] [PubMed]

14. Pranakhon, R.; Aromdee, C.; Pannangpetch, P. Effects of iriflophenone 3-C- $\beta$-glucoside on fasting blood glucose level and glucose uptake. Pharmacogn. Mag. 2015, 11, 82-89. [PubMed]

15. Hara, H.; Ise, Y.; Morimoto, N.; Shimazawa, M.; Ichihashi, K.; Ohyama, M.; Iinuma, M. Laxative effect of agarwood leaves and its mechanism. Biosci. Biotechnol. Biochem. 2008, 72, 335-345. [CrossRef] [PubMed]

16. Jayaraman, S.; Daud, N.; Halis, R.; Mohamed, R. Effects of plant growth regulators, carbon sources and $\mathrm{pH}$ values on callus induction in Aquilaria malaccensis leaf explants and characteristics of the resultant calli. J. For. Res. 2014, 25, 535-540. [CrossRef]

17. Pant, P.; Rastogi, R.P. Agarol, a new sesquiterpene from Aquilaria agallocha. Phytochemistry 1980, 19, 1869-1870. [CrossRef]

18. Gunasekera, S.P.; Kinghorn, A.D.; Cordell, G.A.; Farnsworth, N.R. Plant anticancer agents. XIX. Constituents of Aquilaria malaccensis. J. Nat. Prod. 1981, 44, 569-572. [CrossRef] [PubMed]

19. Dyary, H.O.; Arifah, A.K.; Sharma, R.S.; Rasedee, A.; Mohd-Aspollah, M.S.; Zakaria, Z.A.; Zuraini, A.; Somchit, M.N. Antitrypanosomal screening and cytotoxic effects of selected medicinal plants. Trop. Biomed. 2014, 31, 89-96. [PubMed]

20. Dash, M.; Patra, J.K.; Panda, P.P. Phytochemical and antimicrobial screening of extracts of Aquilaria agallocha Roxb. Afr. J. Biotechnol. 2008, 7, 3531-3534.

21. Jong, P.L.; Tsan, P.; Mohamed, R. Gas chromatography-mass spectrometry analysis of agarwood extracts from mature and juvenile Aquilaria malaccensis. Int. J. Agr. Biol. 2014, 16, 644-648. 
22. Wang, Q.; Matsuda, H.; Matsuhira, K.; Nakamura, S.; Yuan, D.; Yoshikawa, M. Inhibitory effects of thunberginols A, B, and F on degranulations and releases of TNF-alpha; and IL-4 in RBL-2H3 cells. Biol. Pharm. Bull. 2007, 30, 388-392. [CrossRef] [PubMed]

23. Zhang, X.-L.; Wang, L.; Li, F.; Yu, K.; Wang, M.-K. Cytotoxic phorbol esters of Croton tiglium. J. Nat. Prod. 2013, 76, 858-864. [CrossRef] [PubMed]

24. Wang, J.-F.; Yang, S.-H.; Liu, Y.-Q.; Li, D.-X.; He, W.-J.; Zhang, X.-X.; Liu, Y.-H.; Zhou, X.-J. Five new phorbol esters with cytotoxic and selective anti-inflammatory activities from Croton tiglium. Bioorg. Med. Chem. Lett. 2015, 25, 1986-1989. [CrossRef] [PubMed]

25. Wang, G.; Mohan, S.; Negishi, E.-I. Highly selective synthesis of conjugated dienoic and trienoic esters via alkyne elementometalation-Pd-catalyzed cross-coupling. Proc. Natl. Acad. Sci. USA 2011, 108, 11344-11349. [CrossRef] [PubMed]

26. Wang, H.-B.; Wang, X.-Y.; Liu, L.-P.; Qin, G.-W.; Kang, T.-G. Tigliane diterpenoids from the Euphorbiaceae and Thymelaeaceae families. Chem. Rev. 2015, 115, 2975-3011. [CrossRef] [PubMed]

27. Fürstenberger, G.; Hecker, E. On the active principles of the Euphorbiaceae, XII. Highly unsaturated irritant diterpene esters from Euphorbia tirucalli originating from Madagascar. J. Nat. Prod. 1986, 49, 386-397. [CrossRef] [PubMed]

28. Chen, B.H.; Wu, P.Y.; Chen, K.M.; Fu, T.F.; Wang, H.M.; Chen, C.Y. Antiallergic potential on RBL-2H3 cells of some phenolic constituents of Zingiber officinale (Ginger). J. Nat. Prod. 2009, 72, 950-953. [CrossRef] [PubMed]

29. Matsuda, H.; Tewtrakul, S.; Morikawa, T.; Nakamura, A.; Yoshikawa, M. Anti-allergic principles from Thai zedoary: Structural requirements of curcuminoids for inhibition of degranulation and effect on the release of TNF- $\alpha$ and IL-4 in RBL-2H3 cells. Bioorg. Med. Chem. 2004, 12, 5891-5898. [CrossRef] [PubMed]

30. Boyum, A. Isolation of mononuclear cells and granulocytes from human blood. Scand. J. Clin. Lab. Investig. 1968, 97, 77-89.

31. Jauregui, H.O.; Hayner, N.T.; Driscoll, J.L.; Williams-Holland, R.; Lipsky, M.H.; Galletti, P.M. Trypan blue dye uptake and lactate dehydrogenase in adult rat hepatocytes-freshly isolated cells, cell suspensions, and primary monolayer cultures. In Vitro 1981, 17, 1100-1110. [CrossRef] [PubMed]

32. Babior, B.M.; Kipnes, R.S.; Curnutte, J.T. Biological defense mechanisms. The production by leukocytes of superoxide, a potential bactericidal agent. J. Clin. Invest. 1973, 52, 741-744. [CrossRef] [PubMed]

33. Hwang, T.L.; Leu, Y.L.; Kao, S.H.; Tang, M.C.; Chang, H.L. Viscolin, a new chalcone from Viscum coloratum, inhibits human neutrophil superoxide anion and elastase release via a cAMP-dependent pathway. Free Radic. Biol. Med. 2006, 41, 1433-1441. [CrossRef] [PubMed]

34. Lai, W.-C.; Tsui, Y.-T.; Singab, A.N.B.; El-Shazly, M.; Du, Y.-C.; Hwang, T.-L.; Wu, C.-C.; Yen, M.-H.; Lee, C.-K.; Hou, M.-F.; et al. Phyto-SERM Constitutes from Flemingia macrophylla. Int. J. Mol. Sci. 2013, 14, 15578-15594. [CrossRef] [PubMed]

(C) 2016 by the authors; licensee MDPI, Basel, Switzerland. This article is an open access article distributed under the terms and conditions of the Creative Commons by Attribution (CC-BY) license (http://creativecommons.org/licenses/by/4.0/). 